\title{
THE LONG RUN CONSEQUENCES OF UNILATERAL DIVORCE LAWS ON CHILDREN -EVIDENCE FROM SHARELIFE
}

Steffen Reinhold, Thorsten Kneip, Gerrit Bauer

( Mea-Mannheim Research Institute for the Economics of Aging 


\title{
The Long Run Consequences of Unilateral Divorce Laws on Children -Evidence from SHARELIFE*
}

\author{
Steffen Reinhold, MEA, University of Mannheim \\ Thorsten Kneip, MEA, University of Mannheim \\ Gerrit Bauer, MZES, University of Mannheim
}

\begin{abstract}
April 18, 2011
Abstract

Previous research has shown adverse effects of growing up under unilateral divorce laws on long-term outcomes of children. It remains an open question of whether long-term effects of early childhood conditions arise because divorce laws raise the likelihood of parental marital disruption, or whether unilateral divorce laws also affect children in intact marriages by changing intra-household bargaining. Using newly available data from SHARELIFE for eleven Western European countries we address this question employing a differences-indifferences approach and controlling for childhood family structure and socioeconomic status. Like previous research, we find strong adverse effects of growing up under unilateral divorce laws on the well-being of children, and this effect remains even when controlling for childhood variables. We conclude that unilateral divorce laws affect children by changing family bargaining in intact marriages.
\end{abstract}

\footnotetext{
* This paper uses data from SHARELIFE release 1, as of November 24th 2010 or SHARE release 2.4.0, as of March 17th 2011. The SHARE data collection has been primarily funded by the European Commission through the 5th framework programme (project QLK6-CT-2001- 00360 in the thematic programme Quality of Life), through the 6th framework programme (projects SHARE-I3, RII-CT- 2006-062193, COMPARE, CIT5-CT2005-028857, and SHARELIFE, CIT4-CT-2006-028812) and through the 7th framework programme (SHARE-PREP, 211909 and SHARE-LEAP, 227822). Additional funding from the U.S. National Institute on Aging (U01 AG09740-13S2, P01 AG005842, P01 AG08291, P30 AG12815, Y1-AG-4553-01 and OGHA 04064, IAG BSR06-11, R21 AG025169) as well as from various national sources is gratefully acknowledged (see www.share-project.org for a full list of funding institutions).
} 


\section{Introduction}

There is now a large body of literature showing a negative association between parental divorce and children outcomes such as well-being and education (for a meta-analysis see Amato and Keith 1991 and Amato 2001). Furthermore, there is some evidence that liberalized divorce laws in the US (Gruber 2004) and Europe (González and Viitanen 2008) had an adverse effect on children's outcomes. It is an open question, however, whether this effect arises because liberalized divorce laws lead to more divorces or because liberalized divorce laws change the bargaining process within the household and the investment into children's human capital (Gruber 2004) or both. In this paper we address this latter question by exploiting cross-national variation in the introduction of unilateral divorce laws across Europe using a difference-in-differences approach and newly available data from SHARELIFE containing information on family composition and socioeconomic status during childhood. Controlling for these childhood variables allows us to address the question about the mechanism by which liberalized divorce laws affect children's well-being, a question which could not be answered with the data used in Gruber (2004) and González and Viitanen (2008). Using SHARELIFE data has the additional advantage that we can study the long-term effects of divorce legislation over much of the life-cycle as the respondents are 50+ years old whereas typically studies analyzed outcomes in childhood or in young adulthood. We focus on long-term outcomes similar to the ones that have been studied in the literature before: physical and mental health and health behavior (Dawson 1991, Chase-Lansdale et al. 1995, Cherlin et al. 1998), demographic outcomes (Keith and Finlay 1988, Cherlin et al. 1995, Kiernan and Cherlin 1999), and education (Keith and Finlay 1988).

There are three main explanations for the negative effect of divorce on children's outcomes (Amato and Keith 1991): First, usually one parent leaves the household and there is less contact between this parent and the child, and furthermore, the custodial parent may also have competing demands on her time reducing the parental time spent with children. Second, 
divorces are usually associated with economic hardship resulting in lower investments in children's human capital. Third, some argue that it is not divorce per se that is hurting children but family conflicts which lead to a disruption. While some of the literature has controlled for pre-disruption household variables (Chase-Lansdale et al. 1995, Cherlin et al. 1998, Kiernan and Cherlin 1999, Cherlin et al. 1995) there is still the worry that there may be unobserved factors driving both parental marital disruptions and child well-being. In addition, policy makers cannot affect marital disruptions per se but can only reform divorce legislations. For these reasons, some researchers have started looking at the effects of divorce legislation on children's outcomes (Gruber 2004, González and Viitanen 2008). Similarly to the United States, many European countries moved from mutual consent divorce laws to unilateral divorce laws mainly in the 1970's. Under mutual consent law, both partners had to agree to a divorce while under unilateral law one spouse can leave the marriage without the other's consent.

Only if unilateral divorce laws effectively raised divorce rates there would be a possibility that divorce legislation affects children via this channel. However, there is an ongoing controversy whether unilateral divorce laws have in fact increased divorce rates. Becker (1993) argues that under Coasian bargaining there should be no changes in divorce rates. Rather, the introduction of unilateral divorce laws merely shifts the property rights within marriages. Whereas under mutual consent divorce laws the spouse wanting out had to bribe the other he or she can leave unilaterally under the new law. However, in both cases only inefficient marriages are dissolved. Initially, there was support for the notion that unilateral divorce laws lead to an increase in divorce rates (Peters 1986, Friedberg 1998) which was usually interpreted as evidence for some violations of the assumptions of Coase's theorem (no transaction costs, transferability of utility, no informational asymmetries). Wolfers (2006) shows, however, that the increase in divorce rates was not sustained in the United States. Using the same empirical strategy as Wolfers, Kneip and Bauer (2009) and González and 
Viitanen (2009) find a sustained effect of unilateral divorce laws on divorce rates in Western Europe pointing either to a violation of the applicability of Coase's theorem or other indirect effects of unilateral divorce laws for instance because of depressed investments in marriagespecific capital, e.g. decreasing marital fertility. If the change in unilateral divorce laws lead to an increase in divorce rates and divorce itself is bad for children then we expect negative consequences of the change in divorce laws on children's outcomes in Europe.

Regarding the second pathway through which unilateral divorce laws can affect children's outcomes Gruber (2004) discusses the relative bargaining position of both spouses and the resulting allocation of resources and time within the household. If unilateral divorce laws shift resources away from mothers there could be a negative effect on children. Furthermore, under unilateral divorce law women may have a higher incentive to invest in their careers and thus they may also invest less time in household production, fertility, and raising children. Kneip, Bauer, and Reinhold (2011) show that the shift to unilateral divorce laws has increased female labor force participation in Europe. But there could also be beneficial effects of unilateral divorce laws on children's outcomes. Stevenson and Wolfers (2006), for instance, show that there is less distress and physical abuse in families under unilateral divorce laws because it is easier for spouses to leave abusive marriages. They do not investigate directly the consequences of those changes on children's outcomes but it is plausible that for children in such relationships outcomes may improve overall. Furthermore, Rasul (2005) argues that the change of divorce laws may also lead to a better selection into marriages, a notion for which Kneip et al. (2011) find support using SHARELIFE data. Thus, in the long-run the average match quality in marriages may improve and divorce rates may even fall. Children growing up in these better matched marriages may have better outcomes. It is not clear, however, what the average effect on all children would be in this case if there are also more children born out-of-wedlock or in cohabiting unions. 
The question of how divorce laws affect children's outcomes is also of great policy interest. Lundberg and Pollak (1993) argue that governments can use divorce laws to influence intrafamily distribution and well-being of individuals within marriage by shaping their respective position after marital disruption. Understanding the effects of unilateral divorce may then also shed light on other current reforms of divorce and family laws in Europe. For instance, alimony laws were recently reformed in Germany restricting alimonies for homemakers. This would give additional incentives for women to invest in their careers with potentially similar effects on children's outcomes than the shift to unilateral divorce. Thus, it seems to be crucial to assess the impact of family policies and divorce laws on intra-household bargaining to better understand the impact of other social policies on children's outcomes.

\section{Changes in Divorce Laws in Europe}

Divorce laws have undergone several changes in Europe in about the last century. Historically, the first, and maybe most significant, was the introduction of divorce as a legal act, which occurred quite early in most countries. A second change concerns the introduction of "no-fault" grounds for divorce. By the mid of the 20th century those had been adopted by the majority of countries; the remainder followed during the second half of the century. Nofault grounds were sometimes intended as additional to fault grounds, but most countries eventually installed them in replacement thereof. Moreover, where fault grounds have been kept, they have been used decreasingly and usually do not affect the question of alimony payments (Goode, 1993, p. 32). The third change has been a shift from a divorce legislation that requires mutual consent to one that allows for unilateral divorce. Apart from a few outriders and laggards this change mainly took place in the 70 s and early 80 s. Although the shift from mutual-consent to unilateral law is often confused with a shift from fault to no-fault law in the literature (perhaps due to the historical concurrence of their introduction in many legislations), they are conceptionally different. Theoretically, it is the shift to unilateral law that is of main interest here, as it affects the assignment of property rights and, with this, the 
bargaining power of spouses. Consequently, this specific time-varying characteristic constitutes the key explanatory variable of the following analyses. We apply the same coding of this variable as used by Kneip and Bauer (2009), focusing on what they call a de facto unilateral divorce regime. Such a regime is defined as one in which it is possible to file for divorce without the consent of one's spouse. Divorce will then not follow automatically but can be expected to be granted by judicial verdict if certain requirements (like a specified period of separation) are fulfilled.

\section{Data and Empirical Methods}

\subsection{Data}

For our analysis, we use data from SHARELIFE to obtain measures for demographic outcomes, childhood family structure, and socioeconomic status. We match these data to data from waves 1 and 2 from SHARE which contains information on educational attainment, health and health behavior. We restrict our sample to Austria, Germany, Sweden, Netherlands, Spain, Italy, France, Denmark, Greece, Switzerland and Belgium for which we have information on the de facto switch to unilateral divorce law regimes from Kneip and Bauer (2009). This sample restriction results in 14881 to 21326 observations depending on the outcome of interest. Summary statistics on the main variables of interest can be found in table 1 for individuals growing up before and after de facto unilateral divorce laws have been introduced. Overall, it is hard to ascertain whether growing up under unilateral divorce entails disadvantages for children because cohort effects confound this innovation in family law.

\subsection{Empirical Methods}

We employ a differences-in-differences approach where we estimate a basic model of the form:

$$
C O_{i a c}=\alpha+K_{I D U N I_{a c}}{ }^{\prime} \beta+\sum_{a} \eta_{a}+\sum_{c} \eta_{c}+\sum_{c} \eta_{c} * \operatorname{cohort}_{a c}+X_{i a c}{ }^{\prime} \delta+u_{i a c}
$$


where $\mathrm{CO}$ is an outcome for an individual $\mathrm{i}$ of cohort a living in country c, KIDUNI is a dummy variable indicating whether unilateral divorce law was in effect when the individual was 18 years old, $\eta_{a}$ and $\eta_{c}$ are cohort and country fixed effects, respectively, $\eta_{c}{ }^{*}$ cohort $_{a c}$ is a linear cohort trend, and $X$ contains additional control variables capturing the individuals' socioeconomic status of her parents during childhood and an indicator for living together with both biological parents at age 10. By controlling for these individual characteristics of the household during childhood it is possible to control for one mechanism by which unilateral divorce laws affect children's well being. If these laws increase the likelihood of parental marital disruption, and this is the only mechanism, then the coefficients on the childhood variables should absorb much of the effect of unilateral divorce laws and render the coefficient on exposure to unilateral divorce law as a child small and statistically insignificant. On the other hand, if the coefficient on unilateral divorce law is hardly changed after the inclusion of additional control variables for childhood family structure and socioeconomic status, then it is likely that unilateral divorce laws affect children also in intact marriages, for instance by affecting the bargaining positions of spouses. Another potential advantage of controlling for childhood variables is to increase precision of estimates if these variables are important predictors of long-term outcomes.

In addition to the availability of childhood variables, the use of SHARELIFE data has several advantages but also disadvantages compared to Gruber's (2004) use of US census data. First of all, using cross-national variation has the marked disadvantage that the European countries are potentially less homogenous than the 50 US states. Therefore, the assumption that the treatment group countries would have followed the same trend as control group countries if there had been no introduction of unilateral divorce laws is more likely to be violated. We therefore test our results by checking whether the exact definition of the control groups in our experimental setting has a great influence on our results. Restricting our sample to groups of more homogenous countries, as for instance Scandinavia, gives more confidence in our 
results. The use of cross-national European data is also a virtue compared to US census data. The US census only contains state of birth and state of residence and therefore results could be biased because of selective migration in this kind of analysis (Gruber 2004, Heckman, Layne-Farrar, and Todd 1996). This problem should be less severe because there is less migration across national borders in Europe as there is migration across state borders in the United States. Furthermore, migration in Europe is probably not related to differences in divorce laws as usually the divorce laws of the country where the marriage is contracted are applied (González and Viitanen 2009).

\section{Results}

The results for the basic model specification are shown in Table 2, panel A. In the first row, results are shown for a basic model without further covariates and without a country-specific linear trend. According to these estimates, unilateral divorce law has no appreciable effect on adults' completed education, overweight, self-rated health, or depressive symptoms. One finds, however, marked effects on the probability of ever being married (-3 percentage points) and having kids (-5 percentage points). Furthermore, individuals growing up under unilateral divorce laws have a marked reduction of ever starting smoking (-6 percentage points). These results are not strongly affected by the inclusion of controls for family structure and socioeconomic status during childhood (panel B), except for the effect on overweight which increases in size and becomes statistically significant, perhaps because the estimates get more precise. Growing up under unilateral divorce increases the probability of being overweight later on in life ( +4 percentage points).

---Table 2 about here---

This leads us tentatively to conclude that the effect of unilateral divorce laws on children's outcomes is mainly driven by their effects on intra-household bargaining in existing marriages. Gruber (2004) uses a back-of-the-envelope calculation to gauge whether changes in divorce probabilities can account for the effects on children's outcomes and comes to a 
similar conclusion than we do. Gruber finds quite substantial effects of unilateral divorce laws on children's later-life outcomes, but only relatively small effects on the likelihood of parental, marital disruption. If unilateral divorce laws affect later life outcomes only by changing this probability then parental divorce would have to have a very large effect because only a small group is affected but one finds relatively large effects in the whole population. He concludes that these effects would have to be too large to be credible leading him to believe that unilateral divorce laws must also affect the outcomes of children in intact marriages. Our results are re-assuring for his conclusion because he was not able to directly use micro-data on whether the children's parents have in fact separated. Our results for health behaviors also mirror Gruber's results for the United States who has also shown some adverse effects on adults who have grown up under unilateral divorce. However, we find exactly the opposite effect on family formation and child bearing than Gruber did. Whereas he found earlier marriages and earlier children, we find that individuals growing up under unilateral divorce are less likely to get married and they also have fewer children.

\section{Robustness Checks}

In this section, we probe the robustness of our results. We first use an alternative specification of exposure to unilateral divorce laws in youth as our explanatory variable, second, we check different specifications of country-specific cohort effects whether unobserved trends are driving our results, and third, we restrict our samples to get more homogenous control groups.

\subsection{Alternative Specification of Exposure to Unilateral Divorce Laws}

Our definition of exposure to unilateral divorce laws is somewhat arbitrary. It takes the value of 1 if unilateral divorce laws were in place when the individual was 18 years old, zero otherwise. This basic specification facilitates comparison with Gruber (2004) and González and Viitanen, however, at the same time we lose valuable identifying information. As an 
alternative specification, we construct a variable measuring the years of exposure to unilateral divorce laws before the $18^{\text {th }}$ birthday. ${ }^{\dagger}$ The results are presented in table 3 .

---Table 3 about here---

The results using this alternative specification are qualitatively similar to the results of the basic specification. We find strong effects of exposure to unilateral divorce laws on family formation and the probability of having kids. Because we do have little theoretical guidance which is the correct measure of childhood exposure to unilateral divorce laws it is reassuring that the exact definition does not seem to play a major role in driving our main results.

\subsection{Country-Specific Trends}

Another concern with our identification strategy is that there are no unobserved countryspecific cohort trends which are correlated with the change in unilateral divorce laws. There are a couple of noteworthy policy initiatives in Europe affecting our outcomes which are potentially correlated with changes in unilateral divorce laws. All European countries experienced an educational expansion during this period potentially masking the effects of the changes in unilateral divorce laws. The extension of mandatory schooling which roughly falls into the same period (see for instance Pischke and von Wachter 2008). For Germany, Jürges, Reinhold, and Salm (2009) and Kemptner, Jürges, and Reinhold have found a positive effect of education on health behavior when using school constructions or mandatory schooling, respectively, as instruments. Thus, our results for unilateral divorce laws are potentially tainted those by policies happening at the same time as changes in divorce laws. While we do not want to model the potential effects of those other policy initiatives, we use more flexible country specific cohort trends to control in a flexible way for those policy changes. In

\footnotetext{
${ }^{\dagger}$ Notice that there is a second interpretation of this variable, as it implicitly is also a control for the age of the individual when unilateral divorce laws were introduced. In our data set we cannot distinguish between those opportunities.
} 
particular, we include linear, quadratic and cubic country-specific cohort trends in our specifications. These results are presented in Table 4.

---Table 4---

We find that the coefficient estimates on unilateral divorce laws are remarkably stable when controlling for a linear or quadratic trend. However, when including a cubic trend some of our estimates lose statistical significance. However, in most cases even though the coefficient estimates are not significant anymore, the point estimates are still rather close to the point estimates when not controlling for country-specific trends. Therefore, we do not think that our results are mainly driven by unobserved country specific trends which are correlated with unilateral divorce laws.

\subsection{Sample Restrictions}

\subsubsection{Dropping Southern Europe}

One concern with our estimates is that identification relies on the usual assumption of differences-in-differences estimates that we have found a suitable control group. In our case, identification mainly hinges on Denmark and the Netherlands while the other countries are either always in the treatment group (Sweden) or remain in the control group. In particular, the question arises whether Southern European countries are a good control group for the experiences in Denmark and the Netherlands. There are large religious differences between Southern Europe and Denmark and the Netherlands, and in addition divorce became only legal in Spain after the end of the Franco period in 1981. At the same time, economic growth was faster in Spain after it got admitted to the EU. Therefore, trends in outcomes could very well differ between Southern Europe and Denmark and the Netherlands violating the assumptions behind the differences-in-differences approach.

We therefore present additional results where we drop the Southern European countries from our analysis. The results are presented in table 5 
Overall, it does not appear that the exclusion of Southern European countries from our sample affects the results much. In contrast to the complete sample, the effect on overweight becomes insignificant but the effects on smoking and family formation are remarkably similar to our baseline results.

\subsubsection{Restrict Sample to Denmark and Sweden}

We can even go one step further and restrict our sample to just Denmark and Sweden which are probably the two most homogenous countries in our sample. Sweden had introduced unilateral divorce already in 1915 and thus serves as a control group for Denmark introducing unilateral divorce in the 1970's. The results for this robustness check are presented in table 6 . ---Table 6 about here---

When restricting the sample to Denmark and Sweden, we use robust standard errors because estimation of clustered standard errors becomes too problematic with two clusters. Overall we confirm our previous results about the effect of unilateral divorce on health behaviors and family formation. In addition, we find a negative effect of unilateral divorce laws on educational attainment similar to Gruber's results for the United States.

\section{Conclusion}

Starting from Lundberg and Pollak's (1993) theoretical insight that the welfare of divorced parents has an effect on intra-household allocation of intact marriages we examine the change in unilateral divorce laws in Europe and its effect on children's outcomes. Theoretically, it is not clear how this shift in property rights within marriages should affect children's welfare as there are opposing forces at work. Stevenson and Wolfers (2006) show a reduction in family distress after the introduction of unilateral divorce laws, and Rasul (2005) argues that marriages should be better matched after the introduction of unilateral divorce regimes. While we cannot investigate the development of family distress in our data set, we find some support for Rasul's notion that average match quality in marriages increases in a companion paper 
(Kneip, Bauer, and Reinhold 2011). On the other hand, this study also finds an increase in female labor force participation in response to the introduction of unilateral divorce, and Gruber (2004) finds negative effects of unilateral divorce laws on children's welfare in the United States. Overall, our results are confirming Gruber's results for the United States as we find sizable negative effects of the exposure to unilateral divorce laws on health behavior of children and, at least for the Scandinavian countries, on educational attainment. These results are not driven by the effect on unilateral divorce laws on the probability of parental separation because if we condition on living in an intact family at age 10 our estimates are hardly changed. We therefore conclude that the introduction of unilateral divorce laws changed the interactions of parents within the household and reduced investments into children, for instance because less time is spent with children as both parents have to work full-time to maintain their outside options as marriage has lost part of its insurance value. Notice that our data do not allow us to investigate Rasul's hypothesis further for the parents of the individuals in our sample regarding improved selection into marriage because all their parents would have married before the introduction of unilateral divorce laws, except in Sweden. For younger cohorts this may play a role with an ambiguous effect on overall child welfare: it would be beneficial for children born in wedlock but potentially detrimental to children out-of-wedlock. If more children are born out-of-wedlock after the introduction of unilateral divorce the overall effect can even be negative.

Our estimates have important policy implications as more recently family policies have again been the focus of attention of policy-makers. For instance, alimony payments have been reformed in Germany recently. In light of our results, this may also affect children in intact families as it affects the bargaining position of women within the household. [] 


\section{Tables}

Table 1: Summary statistics

De facto unilateral divorce law in

effect at age 18

\begin{tabular}{|c|c|c|c|}
\hline & 0 & 1 & Total \\
\hline \multirow{2}{*}{$\begin{array}{l}\text { Years of } \\
\text { schooling }\end{array}$} & 9.701 & 11.09 & 9.876 \\
\hline & (4.628) & (3.286) & $(4.504)$ \\
\hline \multirow[t]{2}{*}{ Ever married } & 0.941 & 0.915 & 0.937 \\
\hline & $(0.236)$ & $(0.279)$ & $(0.242)$ \\
\hline \multirow[t]{2}{*}{ Has kids } & 0.871 & 0.870 & 0.871 \\
\hline & $(0.335)$ & $(0.337)$ & $(0.335)$ \\
\hline \multirow[t]{2}{*}{ Never smoked } & 0.511 & 0.411 & 0.499 \\
\hline & $(0.500)$ & $(0.492)$ & $(0.500)$ \\
\hline \multirow[t]{2}{*}{ Overweight } & 0.631 & 0.573 & 0.624 \\
\hline & $(0.483)$ & $(0.495)$ & $(0.484)$ \\
\hline \multirow[t]{2}{*}{ Self-rated health } & 0.133 & 0.228 & 0.145 \\
\hline & $(0.340)$ & $(0.419)$ & $(0.352)$ \\
\hline \multirow{2}{*}{$\begin{array}{l}\text { Depressive } \\
\text { symptoms }(0 / 1)\end{array}$} & 0.231 & 0.170 & 0.224 \\
\hline & $(0.422)$ & $(0.376)$ & $(0.417)$ \\
\hline \multirow[t]{2}{*}{ Year of birth } & 1941.2 & 1945.2 & 1941.7 \\
\hline & (21.98) & (9.896) & (20.90) \\
\hline \multirow[t]{2}{*}{ Female } & 0.545 & 0.566 & 0.548 \\
\hline & $(0.498)$ & $(0.496)$ & $(0.498)$ \\
\hline \multirow{2}{*}{$\begin{array}{l}\text { House had poor } \\
\text { standard }\end{array}$} & 0.274 & 0.117 & 0.254 \\
\hline & $(0.446)$ & $(0.321)$ & $(0.436)$ \\
\hline \multirow{2}{*}{$\begin{array}{l}\text { No books in } \\
\text { household }\end{array}$} & 0.489 & 0.187 & 0.452 \\
\hline & $(0.500)$ & $(0.390)$ & $(0.498)$ \\
\hline \multirow{2}{*}{$\begin{array}{l}\text { Lived with both } \\
\text { biological } \\
\text { parents }\end{array}$} & 0.901 & 0.876 & 0.898 \\
\hline & (0.299) & $(0.329)$ & $(0.303)$ \\
\hline
\end{tabular}

Note: Mean and std. deviation in parentheses. 
Table 2: Basic Specification

\begin{tabular}{|c|c|c|c|c|c|c|c|}
\hline & $\begin{array}{l}\text { (1) } \\
\text { Years of } \\
\text { education }\end{array}$ & $\begin{array}{l}\text { (2) } \\
\text { Ever } \\
\text { married }\end{array}$ & $\begin{array}{l}(3) \\
\text { Has } \\
\text { children }\end{array}$ & $\begin{array}{l}(4) \\
\text { Never } \\
\text { smoked }\end{array}$ & $\begin{array}{l}\text { (5) } \\
\text { Overweight }\end{array}$ & $\begin{array}{l}(6) \\
\text { Self-rated } \\
\text { health }\end{array}$ & $\begin{array}{l}\text { (7) } \\
\text { Depressive } \\
\text { symptoms }\end{array}$ \\
\hline \multicolumn{8}{|c|}{ Panel A: Basic specification } \\
\hline kiduni18 & $\begin{array}{l}-0.110 \\
(0.186)\end{array}$ & $\begin{array}{l}-0.0311^{* *} \\
(0.0127)\end{array}$ & $\begin{array}{l}-0.0465^{\star * *} \\
(0.0120)\end{array}$ & $\begin{array}{l}-0.0623^{\star *} \\
(0.0276)\end{array}$ & $\begin{array}{l}0.0285 \\
(0.0210)\end{array}$ & $\begin{array}{l}-0.0173 \\
(0.0183)\end{array}$ & $\begin{array}{l}-0.0131 \\
(0.0129)\end{array}$ \\
\hline $\mathrm{N}$ & 15206 & 21777 & 21786 & 21795 & 21795 & 21794 & 20835 \\
\hline \multicolumn{8}{|c|}{ Panel B: Controlling for childhood SES and family background } \\
\hline kiduni18 & $\begin{array}{l}0.114 \\
(0.190)\end{array}$ & $\begin{array}{l}-0.0324^{* *} \\
(0.0132)\end{array}$ & $\begin{array}{l}-0.0445^{\star * *} \\
(0.0118)\end{array}$ & $\begin{array}{l}-0.0819^{* * *} \\
(0.0234)\end{array}$ & $\begin{array}{l}0.0397^{\star *} \\
(0.0126)\end{array}$ & $\begin{array}{l}-0.00859 \\
(0.0199)\end{array}$ & $\begin{array}{l}-0.0122 \\
(0.0129)\end{array}$ \\
\hline poorhous & $\begin{array}{l}-1.281^{* * *} \\
(0.257)\end{array}$ & $\begin{array}{l}0.00830^{*} \\
(0.00449)\end{array}$ & $\begin{array}{l}0.0147 \\
(0.0104)\end{array}$ & $\begin{array}{l}0.0473^{* *} \\
(0.0154)\end{array}$ & $\begin{array}{l}0.0330^{* * *} \\
(0.00949)\end{array}$ & $\begin{array}{l}-0.0195^{*} \\
(0.00995)\end{array}$ & $\begin{array}{l}0.000571 \\
(0.0156)\end{array}$ \\
\hline nobooks & $\begin{array}{l}-2.451^{\star * *} \\
(0.236)\end{array}$ & $\begin{array}{l}0.00638 \\
(0.00503)\end{array}$ & $\begin{array}{l}0.0156^{\star *} \\
(0.00661)\end{array}$ & $\begin{array}{l}0.0261^{*} \\
(0.0119)\end{array}$ & $\begin{array}{l}0.0646^{* * *} \\
(0.0129)\end{array}$ & $\begin{array}{l}-0.0425^{\star \star *} \\
(0.00528)\end{array}$ & $\begin{array}{l}0.0574^{* * *} \\
(0.00758)\end{array}$ \\
\hline intactat10 & $\begin{array}{l}0.324^{* *} \\
(0.109)\end{array}$ & $\begin{array}{l}-0.00158 \\
(0.00540)\end{array}$ & $\begin{array}{l}-0.00628 \\
(0.00850)\end{array}$ & $\begin{array}{l}0.0445^{\star *} \\
(0.0141)\end{array}$ & $\begin{array}{l}-0.0221^{*} \\
(0.0107)\end{array}$ & $\begin{array}{l}0.0106 \\
(0.00684)\end{array}$ & $\begin{array}{c}-0.0255^{\star *} \\
(0.00925)\end{array}$ \\
\hline $\mathrm{N}$ & 14881 & 21326 & 21326 & 21326 & 21326 & 21326 & 20405 \\
\hline
\end{tabular}

Standard errors in parentheses

${ }^{*} p<0.1,{ }^{* *} p<0.05,{ }^{* * *} p<0.01$

Note: Clustered standard errors in parentheses. All regressions control for country fixed effects, cohort fixed effects, country-specific linear cohort trends, and gender. ${ }^{*} 10 \%{ }^{* *} 5 \%{ }^{* * *} 1 \%$ significance levels. 
Table 3: Alternative Specification of Exposure to Unilateral Divorce

\begin{tabular}{|c|c|c|c|c|c|c|c|}
\hline & $\begin{array}{l}(1) \\
\text { Years of } \\
\text { education }\end{array}$ & $\begin{array}{l}(2) \\
\text { Ever } \\
\text { married }\end{array}$ & $\begin{array}{l}\text { (3) } \\
\text { Has } \\
\text { children }\end{array}$ & $\begin{array}{l}(4) \\
\text { Never } \\
\text { smoked }\end{array}$ & $\begin{array}{l}\text { (5) } \\
\text { Overweight }\end{array}$ & $\begin{array}{l}(6) \\
\text { Self-rated } \\
\text { health }\end{array}$ & $\begin{array}{l}\text { (7) } \\
\text { Depressive } \\
\text { symptoms }\end{array}$ \\
\hline \multicolumn{8}{|c|}{ Panel A: Basic specification } \\
\hline expose18 & $\begin{array}{l}0.0380 \\
(0.125)\end{array}$ & $\begin{array}{l}-0.0134^{* *} \\
(0.00476)\end{array}$ & $\begin{array}{l}-0.0149^{* *} \\
(0.00474)\end{array}$ & $\begin{array}{l}-0.0304^{* * *} \\
(0.00590)\end{array}$ & $\begin{array}{l}0.000105 \\
(0.00722)\end{array}$ & $\begin{array}{l}-0.00307 \\
(0.00380)\end{array}$ & $\begin{array}{l}0.00221 \\
(0.00342)\end{array}$ \\
\hline $\mathrm{N}$ & 15206 & 21777 & 21786 & 21795 & 21795 & 21794 & 20835 \\
\hline \multicolumn{8}{|c|}{ Panel B: Controlling for childhood SES and family background } \\
\hline expose18 & $\begin{array}{l}0.0902 \\
(0.0898)\end{array}$ & $\begin{array}{l}-0.0134^{* *} \\
(0.00528)\end{array}$ & $\begin{array}{l}-0.0146^{* * *} \\
(0.00440)\end{array}$ & $\begin{array}{l}-0.0355^{\star * *} \\
(0.00500)\end{array}$ & $\begin{array}{l}-0.000238 \\
(0.00778)\end{array}$ & $\begin{array}{l}-0.000741 \\
(0.00365)\end{array}$ & $\begin{array}{l}0.00267 \\
(0.00375)\end{array}$ \\
\hline poorhous & $\begin{array}{l}-1.281^{* * *} \\
(0.257)\end{array}$ & $\begin{array}{l}0.00832^{*} \\
(0.00451)\end{array}$ & $\begin{array}{l}0.0146 \\
(0.0104)\end{array}$ & $\begin{array}{l}0.0474^{* *} \\
(0.0154)\end{array}$ & $\begin{array}{l}0.0333^{* * *} \\
(0.00956)\end{array}$ & $\begin{array}{l}-0.0196^{*} \\
(0.00993)\end{array}$ & $\begin{array}{l}0.000455 \\
(0.0156)\end{array}$ \\
\hline nobooks & $\begin{array}{l}-2.451^{* * *} \\
(0.236)\end{array}$ & $\begin{array}{l}0.00637 \\
(0.00502)\end{array}$ & $\begin{array}{l}0.0156^{* *} \\
(0.00663)\end{array}$ & $\begin{array}{l}0.0261^{*} \\
(0.0119)\end{array}$ & $\begin{array}{l}0.0646^{* * *} \\
(0.0130)\end{array}$ & $\begin{array}{l}-0.0426^{* * *} \\
(0.00527)\end{array}$ & $\begin{array}{l}0.0573^{* * *} \\
(0.00756)\end{array}$ \\
\hline intactat10 & $\begin{array}{l}0.324^{* *} \\
(0.109)\end{array}$ & $\begin{array}{l}-0.00148 \\
(0.00542)\end{array}$ & $\begin{array}{l}-0.00617 \\
(0.00853)\end{array}$ & $\begin{array}{l}0.0448^{* *} \\
(0.0142)\end{array}$ & $\begin{array}{l}-0.0222^{*} \\
(0.0107)\end{array}$ & $\begin{array}{l}0.0106 \\
(0.00685)\end{array}$ & $\begin{array}{l}-0.0255^{\star *} \\
(0.00924)\end{array}$ \\
\hline $\mathrm{N}$ & 14881 & 21326 & 21326 & 21326 & 21326 & 21326 & 20405 \\
\hline
\end{tabular}

Standard errors in parentheses

${ }^{*} p<0.1,{ }^{* *} p<0.05,{ }^{* * *} p<0.01$

Note: Clustered standard errors in parentheses. All regressions control for country fixed effects, cohort fixed effects, country-specific linear cohort trends, and gender. 
Table 4: More Flexible Country-Specific Cohort Trends

$\begin{array}{lllllll}(1) & (2) & (3) & (4) & (5) & (6) & (7) \\ \text { Years of } & \text { Ever } & \text { Has } & \text { Never } & & \text { Self-rated } & \text { Depressive } \\ \text { education } & \text { married } & \text { children } & \text { smoked } & \text { Overweight } & \text { health } & \text { symptoms }\end{array}$

Panel A: basic specification (linear country-specific cohort trends)

$\begin{array}{llllllll}\text { kiduni18 } & -0.110 & -0.0311^{* *} & -0.0465^{\star * *} & -0.0623^{\star *} & 0.0285 & -0.0173 & -0.0131\end{array}$

$\begin{array}{llllll}(0.186) & (0.0127) & (0.0120) & (0.0276) & (0.0210) & (0.0183)\end{array}$

Panel B: quadratic country-specific cohort trends

$\begin{array}{llllllll}\text { kiduni18 } & -0.0883 & -0.0300^{* *} & -0.0423^{* * *} & -0.0804^{* * *} & 0.0420^{* *} & -0.0118 & -0.0149 \\ & (0.197) & (0.0132) & (0.0117) & (0.0250) & (0.0145) & (0.0190) & (0.0135)\end{array}$

Panel C: cubic country-specific cohort trends

$\begin{array}{llllllll}\text { kiduni18 } & -0.00965 & -0.0255^{\star *} & -0.0180 & -0.0427 & 0.0212 & 0.00403 & -0.0104 \\ & (0.255) & (0.0114) & (0.0298) & (0.0475) & (0.0158) & (0.0271) & (0.0159) \\ N & 15206 & 21777 & 21786 & 21795 & 21795 & 21794 & 20835\end{array}$

Standard errors in parentheses

${ }^{*} p<0.1,{ }^{* *} p<0.05,{ }^{* * *} p<0.01$

Note: Clustered standard errors in parentheses. All regressions control for country fixed effects, cohort fixed effects, country-specific linear cohort trends, and gender. 
Table 5: Dropping Southern Europe

\begin{tabular}{|c|c|c|c|c|c|c|c|}
\hline & $\begin{array}{l}\text { (1) } \\
\text { Years of } \\
\text { education }\end{array}$ & $\begin{array}{l}\text { (2) } \\
\text { Ever } \\
\text { married }\end{array}$ & $\begin{array}{l}\text { (3) } \\
\text { Has } \\
\text { children }\end{array}$ & $\begin{array}{l}(4) \\
\text { Never } \\
\text { smoked }\end{array}$ & $\begin{array}{l}\text { (5) } \\
\text { Overweight }\end{array}$ & $\begin{array}{l}(6) \\
\text { Self-rated } \\
\text { health }\end{array}$ & $\begin{array}{l}\text { (7) } \\
\text { Depressive } \\
\text { symptoms }\end{array}$ \\
\hline \multicolumn{8}{|c|}{ Panel A: Basic specification } \\
\hline kiduni18 & $\begin{array}{l}-0.255^{*} \\
(0.121)\end{array}$ & $\begin{array}{l}-0.0229^{* *} \\
(0.00943)\end{array}$ & $\begin{array}{l}-0.0418^{* * *} \\
(0.0102)\end{array}$ & $\begin{array}{l}-0.0558 \\
(0.0319)\end{array}$ & $\begin{array}{l}0.0101 \\
(0.0217)\end{array}$ & $\begin{array}{l}0.00936 \\
(0.0182)\end{array}$ & $\begin{array}{l}-0.00515 \\
(0.0210)\end{array}$ \\
\hline N & 10376 & 14545 & 14553 & 14561 & 14561 & 14560 & 13971 \\
\hline \multicolumn{8}{|c|}{ Panel B: Controlling for childhood SES and family background } \\
\hline kiduni18 & $\begin{array}{l}0.0567 \\
(0.174)\end{array}$ & $\begin{array}{l}-0.0221^{*} \\
(0.0102)\end{array}$ & $\begin{array}{l}-0.0360^{\star *} \\
(0.0109)\end{array}$ & $\begin{array}{l}-0.0756^{\star *} \\
(0.0266)\end{array}$ & $\begin{array}{l}0.0207 \\
(0.0119)\end{array}$ & $\begin{array}{l}0.0210 \\
(0.0193)\end{array}$ & $\begin{array}{l}-0.00499 \\
(0.0228)\end{array}$ \\
\hline poorhous & $\begin{array}{l}-1.489^{\star * *} \\
(0.288)\end{array}$ & $\begin{array}{l}-0.00168 \\
(0.00278)\end{array}$ & $\begin{array}{l}0.00554 \\
(0.00917)\end{array}$ & $\begin{array}{l}0.0513^{\star *} \\
(0.0155)\end{array}$ & $\begin{array}{l}0.0406^{\star *} \\
(0.0128)\end{array}$ & $\begin{array}{l}-0.0369^{* * *} \\
(0.00932)\end{array}$ & $\begin{array}{l}-0.0186 \\
(0.0214)\end{array}$ \\
\hline nobooks & $\begin{array}{l}-2.403^{\star * *} \\
(0.295)\end{array}$ & $\begin{array}{l}0.00314 \\
(0.00714)\end{array}$ & $\begin{array}{l}0.0139 \\
(0.00919)\end{array}$ & $\begin{array}{l}0.00871 \\
(0.0132)\end{array}$ & $\begin{array}{l}0.0716^{* * *} \\
(0.0151)\end{array}$ & $\begin{array}{l}-0.0435^{\star * *} \\
(0.00714)\end{array}$ & $\begin{array}{l}0.0543^{* * *} \\
(0.00956)\end{array}$ \\
\hline intactat10 & $\begin{array}{l}0.413^{\star * *} \\
(0.0999)\end{array}$ & $\begin{array}{l}0.00167 \\
(0.00643)\end{array}$ & $\begin{array}{l}-0.00554 \\
(0.00892)\end{array}$ & $\begin{array}{l}0.0586^{\star * *} \\
(0.0150)\end{array}$ & $\begin{array}{l}-0.0125 \\
(0.0121)\end{array}$ & $\begin{array}{l}0.00903 \\
(0.00868)\end{array}$ & $\begin{array}{l}-0.0300^{\star *} \\
(0.0109)\end{array}$ \\
\hline $\mathrm{N}$ & 10102 & 14171 & 14171 & 14171 & 14171 & 14171 & 13616 \\
\hline
\end{tabular}

Standard errors in parentheses

${ }^{*} p<0.1,{ }^{* *} p<0.05,{ }^{* * *} p<0.01$

Note: Clustered standard errors in parentheses. All regressions control for country fixed effects, cohort fixed effects, country-specific linear cohort trends, and gender. 
Table 6: Sweden and Denmark only

\begin{tabular}{|c|c|c|c|c|c|c|c|}
\hline & $\begin{array}{l}(1) \\
\text { iscedy } r\end{array}$ & $\begin{array}{l}\text { (2) } \\
\text { evrmarr }\end{array}$ & $\begin{array}{l}\text { (3) } \\
\text { haskids }\end{array}$ & $\begin{array}{l}\text { (4) } \\
\text { neversmok }\end{array}$ & $\begin{array}{l}\text { (5) } \\
\text { overweight }\end{array}$ & $\begin{array}{l}\text { (6) } \\
\text { saheu }\end{array}$ & $\begin{array}{l}\text { (7) } \\
\text { eurodcat }\end{array}$ \\
\hline \multicolumn{8}{|c|}{ Panel A: Basic specification } \\
\hline kiduni18 & $\begin{array}{l}-0.758^{*} \\
(0.0792)\end{array}$ & $\begin{array}{l}-0.0238^{* *} \\
(0.000980)\end{array}$ & $\begin{array}{l}-0.0278^{*} \\
(0.00268)\end{array}$ & $\begin{array}{l}-0.133^{* *} \\
(0.00493)\end{array}$ & $\begin{array}{l}0.0648^{*} \\
(0.0103)\end{array}$ & $\begin{array}{l}0.0363^{* *} \\
(0.00174)\end{array}$ & $\begin{array}{l}0.0266 \\
(0.0163)\end{array}$ \\
\hline $\mathrm{N}$ & 2573 & 3887 & 3890 & 3890 & 3890 & 3890 & 3773 \\
\hline \multicolumn{8}{|c|}{ Panel B: Controlling for childhood SES and family background } \\
\hline kiduni18 & $\begin{array}{l}-0.774^{*} \\
(0.0897)\end{array}$ & $\begin{array}{l}-0.0242^{* *} \\
(0.00128)\end{array}$ & $\begin{array}{l}-0.0283^{*} \\
(0.00395)\end{array}$ & $\begin{array}{l}-0.132^{* *} \\
(0.00483)\end{array}$ & $\begin{array}{l}0.0661 \\
(0.0114)\end{array}$ & $\begin{array}{l}0.0397^{\star *} \\
(0.00256)\end{array}$ & $\begin{array}{l}0.0375 \\
(0.0162)\end{array}$ \\
\hline poorhous & $\begin{array}{l}-1.022 \\
(0.169)\end{array}$ & $\begin{array}{l}0.000844 \\
(0.000663)\end{array}$ & $\begin{array}{l}-0.0224 \\
(0.0129)\end{array}$ & $\begin{array}{l}0.0255^{\star \star *} \\
(0.0000795)\end{array}$ & $\begin{array}{l}0.0493^{*} \\
(0.00761)\end{array}$ & $\begin{array}{l}-0.0548 \\
(0.0226)\end{array}$ & $\begin{array}{l}-0.0306^{\star *} \\
(0.00194)\end{array}$ \\
\hline nobooks & $\begin{array}{l}-1.754^{* *} \\
(0.0592)\end{array}$ & $\begin{array}{l}-0.0180 \\
(0.0160)\end{array}$ & $\begin{array}{l}-0.00370 \\
(0.0122)\end{array}$ & $\begin{array}{l}-0.0102 \\
(0.00198)\end{array}$ & $\begin{array}{l}0.0744 \\
(0.0129)\end{array}$ & $\begin{array}{l}-0.0426 \\
(0.0247)\end{array}$ & $\begin{array}{l}0.0319 \\
(0.0211)\end{array}$ \\
\hline intactat10 & $\begin{array}{l}0.435 \\
(0.313)\end{array}$ & $\begin{array}{l}0.00251 \\
(0.0176)\end{array}$ & $\begin{array}{l}-0.0162 \\
(0.0188)\end{array}$ & $\begin{array}{l}0.0953 \\
(0.0386)\end{array}$ & $\begin{array}{l}-0.00307 \\
(0.0200)\end{array}$ & $\begin{array}{l}0.0156^{* *} \\
(0.000345)\end{array}$ & $\begin{array}{l}-0.0464 \\
(0.0181)\end{array}$ \\
\hline $\mathrm{N}$ & 2497 & 3783 & 3783 & 3783 & 3783 & 3783 & 3672 \\
\hline \multicolumn{8}{|c|}{$\begin{array}{l}\text { Standard errors in parentheses } \\
{ }^{*} p<0.1,{ }^{* *} p<0.05,{ }^{* *} p<0.01\end{array}$} \\
\hline
\end{tabular}




\section{Literature}

Amato, Paul R. and Bruce Keith (1991). "Parental Divorce and the Well-Being of Children: A Meta-Analysis," Psychological Bulletin 110(1), 26-46.

Amato, Paul R. (2001). "Children of Divorce in the 1990s: An Update of the Amato and Keith (1991) Meta-Analysis," Journal of Family Psychology 15(3), 355-370.

Becker, Gary S. (1993). A Treatise on the Family. Cambridge, MA: Harvard University Press.

Cherlin, Andrew J., P. Lindsay Chase-Lansdale, and Christine McRae (1998). "Effects of Parental Divorce on Mental Health Throughout the Life Course, "American Sociological Review 63(2), 239-249.

Cherlin, Andrew J., Kathleen E. Kiernan, and P. Lindsay Chase-Lansdale (1995). "Parental Divorce in Childhood and Demographic Outcomes in Young Adulthood," Demography 32(3), 299-318.

Dawson, Deborah A. (1991). "Family Structure and Children's Health and Well-Being: Data from the 1988 National Health Interview Survey on Child Health," Journal of Marriage and Family 53(3), 573-584.

Friedberg, Leora (1998). "Did Unilateral Divorce Raise Divorce Rates? Evidence From Panel Data," American Economic Review 88, 608-627.

González, Libertad and Tarja K. Viitanen (2009). "The Effect of Divorce Laws on Divorce Rates in Europe," European Economic Review 53, 127-138.

---- (2008). “The Long Term Effects of Legalizing Divorce on Children,” IZA Discussion Paper 3789.

Goode, William Josiah (1993): World Changes in Divorce Patterns. New Haven \& London: Yale University Press.

Gruber, Jonathan (2004). "Is Making Divorce Easier Bad for Children? The Long-Run Implications of Unilateral Divorce," Journal of Labor Economics 22(4), 799-833.

Heckman, James J., Anne Layne-Farrar, and Petra Todd (1996). "Does measured school quality really matter? An examination of the earnings quality relationship," in Gary Burtless (ed.) Does Money Matter? Washington D.C., Brookings Institution.

Keith, Verna M. and Barbara Finlay (1988). “The Impact of Parental Divorce on Children's Educational Attainment, Marital Timing, and the Likelihood of Divorce," Journal of Marriage and Family 50(3), 797-809.

Kiernan, Kathleen E. and Andrew J. Cherlin (1999). "Parental Divorce and Partnership Dissolution in Adulthood: Evidence from a British Cohort Study," Population Studies 53(1), 39-48. 
Kneip, Thorsten and Gerrit Bauer (2009). "Did Unilateral Divorce Laws Raise Divorce Rates in Western Europe?” Journal of Marriage and Family 71, 592-607.

Kneip, Thorsten, Gerrit Bauer and Steffen Reinhold (2011) "Unilateral Divorce in Europe. The Mediating Role of Selection into Marriage, Female Labor Force Participation, and Family Formation," Mannheim: Unpublished Manuscript.

P. Lindsay Chase-Lansdale, Andrew J. Cherlin and Kathleen E. Kiernan (1995). "The LongTerm Effects of Parental Divorce on the Mental Health of Young Adults: A Developmental Perspective," Child Development 66(6), 1614-1634.

Lundberg, Shelly and Robert A. Pollak (1993). "Separate Spheres Bargaining and the Marriage Market," Journal of Political Economy 101(6), 988-1010.

Peters, H. Elizabeth (1986). "Marriage and Divorce: Informational Constraints and Private Contracting," American Economic Review 76, 437-454.

Pischke, Jörn-Steffen and Till von Wachter (2008). "Zero Returns to Compulsory Schooling in Germany," Review of Economics and Statistics 90(3), 592-598.

Rasul, Imran (2005). "Marriage Markets and Divorce Laws," Journal of Law, Economics, and Organizations 22(1), 30-68.

Stevenson, Betsey and Justin Wolfers (2006). "Bargaining in the Shadow of the Law: Divorce Laws and Family Distress," Quarterly Journal of Economics 121(1), 267-288. 